\title{
BALANCING GENDER ACHIEVEMENT AND KNOWLEDGE RETENTION IN MATHEMATICS USING COMPUTER ANIMATION INSTRUCTIONAL PACKAGE (CAIP)
}

\author{
${ }^{1}$ Nwoke, Bright lhechukwu Ph.D, ${ }^{2}$ Okorie Simon Chidi and ${ }^{3}$ Chile-Agada, B.U.N \\ ${ }^{1}$ Department of mathematics \\ ${ }^{2,3}$ Department of Computer Education \\ ${ }^{1,2,3}$ Alvan Ikoku Federal college of Education \\ Imo State, Nigeria. \\ ${ }^{1}$ Email:bright.nwoke@alvanikoku.edu.ng Phone No:08033404186
}

\begin{abstract}
The study was carried out to investigate the effectiveness of Computer Animation Instructional Package on balancing gender achievement and knowledge retention in mathematics in secondary schools. The study was a quasi-experimental type adopting the pre-test, posttest non-equivalent control design type. The population of the study comprised of all senior secondary 1(SS1) students of Government owned secondary schools in Owerri North Local Government Area of Imo State. The sample for the study was 225 students from two purposively selected secondary schools consisting of 127 females and 98 males. The instrument for data collection was a researcher made 30-item objective test questions titled "Mathematics achievement Test (MAT)". It had reliability coefficient of 0.91 determined using Kuder-Richardson $\left(K R_{21}\right.$.). The experiment group was taught Surface area and volume of solids using Computer Animation Instructional Package (CAIP) while, the control group was taught the same concept using traditional approach. The data generated was analyzed using mean and standard deviation to answer research questions while the hypotheses were tested at 0.05 level of significance using Analysis of Covariance (ANCOVA). The result of the study revealed that Computer Animation Instructional Package (CAIP) reduced gender disparity associated with mathematics achievement as there was no significant difference between the mean achievement scores of male and female students taught mathematics using Computer Animation Instructional Package (CAIP). Also there was no significant difference between the posttest and delayed posttest mean achievement scores of students taught mathematics using Computer Animation Instructional Package(CAIP). Based on the result it was recommended that, Mathematics teachers should use Computer Animation Instructional Package (CAIP) to teach mathematics as to reduce gender disparity in mathematics achievement and enhance knowledge retention in secondary schools.
\end{abstract}

Keywords: Computer Animation, Gender, Mathematics, Achievement, Retention 


\section{Introduction}

Mathematics is an important subject in the life of every individual as it contributes to wellbeing and development of sound mind. Pierce (2007) defined mathematics as a body of knowledge centered on concepts such as quantity, structure, space, change and also the academic discipline that studies them. Mathematics is one of the formal disciplines that help man lay a solid foundation for future survival. Scientific and technological developments of any nation are dependent on their level of mathematical knowledge. Mishra (2014) stated that mathematics may be seen as the science of magnitude, number, shape, space, and their relationships and also as a universal language based on symbols and diagrams. It involves the handling (arrangement, analysis, manipulation and communication) of information. Mathematics is a branch of science, which deals with numbers and their operations. It involves calculation, computation, solving of problems etc. Its dictionary meaning states that, 'Mathematics is the science of numbers and space' or 'Mathematics is the science of measurement, quantity and magnitude'. It is exact, precise, systematic and a logical subject. Mathematics reveals hidden patterns that help us to understand the world around us (Fatima n.d). Mathematics education encourages the child to think and communicate quantitatively and spatially, solve problems, recognize situations by applying mathematics applications and use appropriate technology to support such applications. If the child is to become an informed and confident member of society he must be enabled to deal effectively with the varied transactions of everyday life and make sense of the mass of information and data available through the media, confident and to communicate effectively through the medium of mathematics (Maccini cited in Mishra, 2014). According to Odhiambo, Maito and Ooko (2013), mathematics all over the world plays a pivotal role in student lives, it is a bridge to science, technology and other subjects offered in any formal educational system. In Nigeria, Mathematics is taught as a core subject to all students at the primary and secondary school le vels in order to give a sound basis for scientific and reflective thinking, and prepare them for $\mathrm{t}$ he next level of education (FRN, 2004).

In spite of the relevance and popularity of mathematics in Nigerian education system, students consistently record poor performance in the area. Miheso (2012) indicated that mathematics is the subject that is poorly performed at national examinations by many secondary school students worldwide. Ugboduma, Ezeamaenyi, and Ogbu (2012) indicated that despite the compulsory nature accorded mathematics at this level, it is unfortunate that most secondary schools' students still fear mathematics and achieve poorly in it. Matawal (2013) laments that despite the relevance of mathematics in the national development, students still perform abysmally low in the subject. Many other research reports (Elekwa, 2010, Uwadiae, 2010, Olunloye, 2010) have variously indicated poor achievement in mathematics by students.

The causes of poor performance in mathematics has been blamed on several factors which includes: lack of instructional resources (Yara, \& Otieno, 2010); Instructional techniques Olunloye (2010), poor interest in mathematics (Badmus, 2002 \& Obodo, 2004), gender difference (Agwagah, 2000) and lack of appropriate instructional materials for teachin $\mathrm{g}$ mathematics at all levels of education in Nigeria (Gambari, 2010).

This poor Mathematics performance of students is further worsened by gender imbalance leading to the problem which now constitutes a major research focus across the globe (UNESCO, 2003 as cited in Bassey, Joshua, \& Asim, 2009). Achor, Imoko and Ajai (2010) in a study, found out that in Nigeria male students perform better than their female 
counterparts in mathematics despite being subjected to the same classroom situation. On the other hand, Kuruma (2004) and Gimba (2006) cited in Mwangi, Changeiywo, and Githua (2020) observed that girls outperform boys in geometrical mathematics in Nigeria when taught using computer animations. Osemmwinyen (2009) and Iwendi (2012) found no gender differences in the performance of male and female students in mathematics. Mbugua (2012) stated that males outperform their female counterparts in Science, Mathematics and Technology subjects. Vale (2009) research revealed that both male and female students perform significantly the same in mathematics achievement; though males obtain higher mean scores. This agrees with Ericikan, McCreikth and Lapointe (2005) whose research revealed no significant difference in mathematics achievement of male and female students. However, there has been no consistency in the direction of gender issues in mathematics achievement and this requires an intervention as to resolve the dichotomy.

Retention which is the ability to reproduce the learnt concept when the need arises has been researched by many researchers (Gambari, Falode, \& Adegbenro, 2014). Sousa (2011) defined retention as "the process whereby long term memory preserves learning in such a way that it can locate, identify, and retrieve it accurately in the future". According to Macmillan English Dictionary as cited in Jega, Muhammad, Libata, and Kamba, (2018) retention is the act of keeping or storing something. It can also be defined as the ability to remember ideas or facts. Retention of what somebody has learnt so as to be able to retrieve it when there is need for that is necessary. Osemmwinyen (2009) found that students' interests and retention could be aroused and retained through the use of an appropriate instructional media like e-learning. In most cases mathematics students do not have the ability to remember mathematics concepts due to lack of retention. Iji, Abakpa and Age (2018) stated that teachers of Mathematics are continually challenged to find the most effective method of teaching students in other to ensure a better students outcome. It therefore becomes necessary to explore technology based teaching in enhancing achievement and facilitating acquisition of the knowledge of what is being taught using online animation instructional packages. Badiei, Gharib, Zolfaghari, and Mojtahedzadeh (2016) stated that, electronic learning enables greater retention of knowledge than simply learning from books.

According to Clark and Mayer as cited in Hamzat, Bello, and Abimbola (2017) animation refers to a computerized simulation of processes using images to structure a synthetic motion picture and adding printed text, charts, maps, static graphics and selfmotivated graphics. Yisa, and Ojiaku (2016) defined Computer Animation as an electronic device or object of instruction in a physical world of matter through a machine with moving objects of many characteristics (shape, pictures, graphic etc) indicating action, reactions, skills results, product in learning process. It transmits information inform of images, sound to be displayed on a screen projector through computer graphic. Ogochukwu (2010) defined animation as making objects on the screen change or move in real time. Computer animation deals with adding live into a still object to enable it move as to represent a live situation and drive home the knowledge of a concept. Computer animation instructional approach helps to build students interest, imaginations, stimulates thinking, concretize knowledge and facilitate understanding of mathematical concepts. Animation has the ability to promote flexibility of learning, enliven the learning experience, allows a wider range of stimuli that increases the students engagement in learning. Research has shown that dynamic teaching methods accompanied by colours, illustrations, and animation can go a long way to enhance both understanding and knowledge 
retention in the learner (Watkins, 2019). Njoku and Eze-Odurukwe (2015) indicated that students' academic achievements are greatly improved when taught with computer animations. Kearsley as cited in Bamidele and Yoade (2017) stated that students who learn from animation have greater self-esteem and motivation. The study also showed that, students retain information and the ability to sustain the learning process increases. Davis and McGrail, (2009) noted that learner-centred instructional strategies can enhance a stimulating learning environment in which learners interest can increase positively and this can lead to increased attention, retention, concentration, knowledge and learning. Gambari et al (2014) in their study concluded that computer animation package was more effective in teaching the mathematical concept of geo metry, improved learners' performance, enhanced their retention, and is also gender friendly. Bamidele and Yoade (2017) stated that Animation instructional package was a better strategy in improving students' achievement in Biology than the conventional teaching method. Mwangi et al (2020) in a study indicated that when computer animations are used to teach Geometry in general and Loci in particular then all students improve academically irrespective of gender.

\section{Statement of the Problem}

The relevance of mathematics in the society cannot be overemphasized as the level of scientific and technological development of any nation generally is dependent on their level of mathematical attainment. However, the state of mathematics teaching and learning seems to be fast deteriorating at secondary school levels in Nigeria as most students are noted to perform poorly in the subject. Some of the factors attributed to the learners' poor performances in mathematics are poor methodology, lack of teaching/learning resources and gender stereotype among others. The gender imbalance associated with mathematics performance will not be favourable to the nations chase for scientific and technological development if allowed to continue. Computer animation packages have been very effective in promoting students' achievement across gender in other subjects than the traditional teaching approach which is teacher centered.

Therefore, the study was carried out to investigate the effectiveness of Computer Animation Instructional Package (CAIP) in balancing the gender achievement and knowledge retention in mathematics at secondary school level.

\section{Purpose of the Study}

The basic purpose of the study was to determine the effectiveness of Computer Animation Instructional Package (CAIP) in balancing gender achievement and knowledge retention in mathematics at secondary school level. Specifically, the study will determine whether;

1) Computer Animation Instructional Package (CAIP) will ensure gender balance in mathematics achievement among secondary school students.

2) Computer Animation Instructional Package (CAIP) will ensure students' retention of mathematical knowledge.

\section{Research Question}

The following research questions guided the study

1) What is the difference between the mean achievement scores of male and female students taught mathematics using Computer Animation Instructional Package (CAIP)? 
2) What is the difference between the posttest and delayed posttest mean achievement scores of students taught mathematics using Computer Animation Instructional Package (CAIP)?

\section{Hypotheses}

The following hypotheses were formulated for the study

Ho: There is no significant difference between the mean achievement scores of male and female students taught mathematics using Computer Animation Instructional Package (CAIP).

Ho: : There is no significant difference between the posttest and delayed posttest mean achievement scores of students taught mathematics using Computer Animation Instructional Package (CAIP).

\section{Methodology}

The study was a quasi-experimental type adopting the pre-test, posttest nonequivalent control design. The population of the study consists of all the senior secondary one (SS1) students of government owned secondary schools in Owerri North Local Government Area of Imo State. Two schools were purposively selected for the study based on their location and availability of ICT facilities which could assist in the study. In each of the schools selected, two intact classes were randomly assigned to control and experiment groups. The experiment group had a total of one hundred and five (105) students comprising of forty five (45) males and sixty (60) females while the control group was made up of one hundred and twenty (120) students consisting of fifty three (53) males and sixty seven (67) females. These gave a total of two hundred and twenty five (225) students with ninety eight (98) males and one hundred and twenty seven (127) females. The instrument for data collection was a researcher made 30-item objective test questions titled "Mathematics achievement Test (MAT)" with four options A-D which includes a correct answer and 3 distractors. The construction of the instrument was guided by a table of specifications based on the mathematical concepts taught the students. The face and content validity of the instrument were validated by two experts in mathematics education and a measurement and evaluation expert from Alvan Ikoku Federal College of Education Owerri. Their expert judgements guided the restructuring of the instrument. The instrument was trial tested on 30 students outside the study sample but having the characteristics, their results were computed using kuder Richardson $\left(\mathrm{KR}_{21}\right)$ formula which gave a reliability coefficient of 0.91 which was acceptable for the study. The Computer Animation Instructional Package (CAIP) used for the study was downloaded from the internet site www.mathswarehouse.com/gifs based on the concept Surface area and volume of solids; cube, cylinder, cuboid, cone. The package was verified by a specialist in computer programming before usage. Before the treatment session, both groups were pretested to determine their cognitive readiness. The experiment groups were taught by a research assistant trained on the application of Computer Animation Instructional Package (CAIP). In this group the research assistant taught the group using an outlined lesson plan which captured the CAIP. In the process the CAIP was downloaded and projected to the board and the research assistant conducted the animation process through moving the objects, showing relationship between each object and plan shapes which was also reflected in the formula for finding surface areas and volumes of objects being taught. The students were allowed to engage in some of the animation activities as to understand some of the relationships associated with the concepts. The control groups were 
simultaneously taught the same concepts by their regular mathematics teachers using a traditional approach lesson plan. The researcher monitored the entire process to ensure compliance with the various lesson plan. The entire process lasted for four weeks after which a posttest was administered using a re-arranged version of the pre-test instrument. After two weeks, a delayed posttest was administered to the experiment group and all the tests were scored over 100 percent. The data generated were analyzed using mean and standard deviation to answer research questions while the hypotheses were tested at 0.05 level of significance using the Analysis of Covariance (ANCOVA).

\section{Results}

Research Question 1: What is the difference between the mean achievement scores of male and female students taught mathematics using Computer Animation Instructional Package (CAIP)?

Table 1: Summary gender achievements in experiment group

\begin{tabular}{lllllll}
\hline Gender & N & Test & Mean & SD & $\begin{array}{l}\text { Mean } \\
\text { gain }\end{array}$ & $\begin{array}{l}\text { Mean } \\
\text { Achievement }\end{array}$ \\
\hline Males & & Pretest & 32.24 & 8.22 & & \\
& 45 & Posttest & 54.47 & 8.07 & 22.13 & 1.20 \\
Females & & Pretest & 31.05 & 8.12 & & \\
& 60 & Posttest & 54.38 & 8.96 & 23.33 & \\
\hline
\end{tabular}

Table 1 shows that male students in the experiment group had pre-test mean of 32.24 and standard deviation of 8.22 with a posttest mean of 54.47 and standard deviation of 8.07 , this gave a mean gain of 22.13. The female students had pre-test mean of 31.05 and standard deviation of 8.12 with a posttest mean of 54.38 and standard deviation of 8.96 , this gave a mean gain of 23.33. These gave a difference in mean achievement of 1.20 in favour of female students.

Research Question 2: What is the difference between the posttest and delayed posttest mean achievement scores of students taught mathematics using Computer Animation Instructional Package (CAIP)?

Table 2: Summary of posttest and delayed posttest achievement of experiment group

\begin{tabular}{|c|c|c|c|c|c|c|}
\hline Group & $\mathbf{N}$ & Test & Mean & SD & Mean gain & Mean Achievement \\
\hline \multirow{4}{*}{ Experiment } & \multirow{4}{*}{105} & Pretest & 31.43 & 8.52 & & \multirow{4}{*}{1.10} \\
\hline & & Posttest & 54.42 & 7.58 & 23.00 & \\
\hline & & Pretest & 31.43 & 8.52 & & \\
\hline & & D/Posttest & 55.52 & 7.61 & 24.10 & \\
\hline
\end{tabular}

Table 2 shows that the experiment group had pre-test of 31.43 and standard deviation of 8.52 with a posttest mean of 54.42 and standard deviation of 7.58, this gave a mean gain of 23.00. They also had delayed posttest mean of 55.52 with standard deviation of 7.61 , this gave a mean gain of 24.10 as compared with the pre-test mean. This gave achievement of 1.10 in favour of the delayed posttest.

Ho: There is no significant difference between the mean achievement scores of male and female students taught mathematics using Computer Animation Instructional Package (CAIP). 


\begin{tabular}{|c|c|c|c|c|c|c|}
\hline Source & $\begin{array}{l}\text { Type111 sum of } \\
\text { squares }\end{array}$ & Df & Mean Square & $\mathbf{F}$ & Sig & Remark \\
\hline Corrected Model & 25714.867 & 4 & 6428.717 & 82.883 & .000 & \\
\hline Intercept & 23698.826 & 1 & 23698.826 & 305.541 & .000 & \\
\hline Covariate & 34.053 & 1 & 34.053 & .439 & .508 & \\
\hline Method & 25416.648 & 1 & 25416.648 & 327.688 & .000 & $\mathbf{S}$ \\
\hline Gender & 130.019 & 1 & 130.019 & 1.676 & .197 & Ns \\
\hline Method*Gender & 175.411 & 1 & 175.411 & 2.262 & .134 & Ns \\
\hline Error & 17063.996 & 220 & 77.564 & & & \\
\hline Total & 460181.000 & 225 & & & & \\
\hline Corrected Total & 42778.862 & 224 & & & & \\
\hline
\end{tabular}

Table 3 shows that $\mathrm{p}$-value of .134 for method*gender column is greater than significant level of 0.05 . Since the p-value is greater than 0.05 significant level, the null hypothesis is upheld.

Ho$_{2}$ : There is no significant difference between the posttest and delayed posttest mean achievement scores of students taught mathematics using Computer Animation Instructional Package (CAIP).

Table 3 also shows that p-value of .125 for method column is greater than significant level of 0.05 . Since the $\mathrm{p}$-value is greater than the significant level, the null hypothesis is upheld.

\section{Discussion}

The result of the study revealed that female students in the experiment group slightly achieved higher than their male counterparts, further statistical analysis revealed no significant difference between the mean achievement scores of male and female students taught mathematics using Computer Animation Instructional Package (CAIP). This implied that the use of Computer Animation Instructional Package (CAIP) enabled both male and female students to gain achievement in mathematics. It enabled students be motivated, develop needed interest to learn mathematics and had better understanding of mathematics concepts irrespective of their gender. Also, it did not give room for sex stereotype, competition but allowed for cooperative and collaborative learning among the students. This result is in consonance with the results of Bamidele and Yoade (2017), Mwangi et al (2020) and Gambari et al (2014) which variously revealed that Computer animation strategy improved students' academic achievements.

The result also revealed that, students taught mathematics using Computer Animation Instructional Package (CAIP) retained the knowledge gained as their mean achievement scores remained closely related and statistical analysis indicated no significant difference between the posttest and delayed posttest mean achievement scores of students taught mathematics using Computer Animation Instructional Package (CAIP). This may have resulted from the practical nature of the instructional process which enabled the students to regurgitate the knowledge of the concept they were taught. This result is in line with that of Davis and McGrail, (2009) and Osemmwinyen (2009) who stated that student's interest and retention can be sustained using appropriate instructional strategy.

\section{Conclusion}

The results of this study have revealed that the use of Computer Animation Instructional Package (CAIP) balanced gender achievement and enhanced knowledge retention in mathematics at secondary school level. 


\section{Recommendation}

The following recommendations were made based on the result of the study;

1) Mathematics teachers should use Computer Animation Instructional Package (CAIP) to teach mathematics as to balance gender achievement in mathematics and enhance knowledge retention in secondary schools.

2) Workshops/seminars should be organized by Government, NGOs and school managers for Mathematics teachers to enable them learn how to apply Computer Animation Instructional packages (CAIP) in teaching Mathematics.

3) The Government, NGOs and school managers should establish mathematics laboratories equipped with computers and mathematics software to enable students and teachers use them in the teaching learning process. 


\section{References}

Achor, E. E., Imoko, B. I. \& Ajai, J. T. (2010). Sex differentials in students' achievement and interest in geometry using games and simulations technique. Necatibey Faculty of Education. Electronic Journal of Science and Mathematics Education 4(1), 1-10.

Agwagah, U. N. V. (2000). Influence of gender difference of students in their achievement in secondary school mathematics. Abacus, 25(1), 102- 112.

Badiei, M., Gharib, M., Zolfaghari, M.\& Mojtahedzadeh, R. (2016) 'Comparing nurses' knowledge retention following electronic continuous education and educational booklet: a controlled trial study', Medical Journal of Islamic Republic of Iran. , 30(), pp. 364 [Online]. Available at: https://www.ncbi.nlm.nih.gov/pmc/articles/PMC4972056/(Accessed:14/9/2020).

Badmus, G. A. (2002). Interest and attitude as correlated of mathematics achievement of secondary school students. unpublished Paper, Faculty of Education, Uniben.

Bamidele,E.F. \& Yoade,F.B. (2017).Effects of modes of computer animationinstructional packages on students' achievement in OsunState secondary schools' biology. International Journal of Innovation and Research in Educational Sciences 4(4),496501.

Bassey,S.W., Joshua,M.T \& Asim, A.E.(2009). Gender Differences and Mathematics Achievement of RuralSenior Secondary Students in Cross River State, Nigeria. Proceedings of epiSTEME 3International Conference to Review Research in Science,Technology and Mathematics Education.

Davis, A. \& McGrail, E. (2009). "Proof-revising" with podcasting: keeping readers in mind as students listen to and rethistunk their writing. The Reading Teacher 62 (6), 522529.

Elekwa, U. C. C. (2010). Effects of collaborative teaching/learning strategies on the mathematics achievement of senior secondary school students in Abia State of Nigeria. Unpublished Ph.D Thesis, Faculty of Education, University of Port Harcourt

Ericikan, K., McCreith, T., \& Lapointe, V. (2005). Factors associated with mathematics achievement and participation in advanced mathematics courses: An examination of gender difference from an international perspective. School and Mathematics, 105, 5.

Fatima, R. (n.d).Role of mathematics in the development of society. file:///C:/Users/ADMIN/AppData/Local/Temp/RoleofMathematicsintheDevelopmentof Society-2.pdf. Retrieved on $23^{\text {rd }}$ Aug. 2020.

Federal Republic of Nigeria (2004). National policy on education. Lagos: NERDC Press. 
Gambari, A. I. Falode, C. O. \& Adegbenro, D. A.(2014). Effectiveness of computer animation and geometrical instructional model on mathematics achievement and retention among junior secondary school students. European Journal of Science and Mathematics Education 2(2), 127-148.

Gambari, A. I. (2010). Effect of instructional models on the performance of junior secondary school students in geometry in Minna, Nigeria. Delsu Journal of Educational Research and Development, 9(1), 54-65.

Hamzat, A., Bello, G. \& Abimbola, I. O. (2017). Effects of computer animation instructional package on students' achievement in practical biology. Cypriot Journal of Educational Science. 12(4), 218-227. 10.18844/cjes.v12i4.2932

Iji, C.O., Abakpa, B.O. \& Age, T.J. (2018). Effect of geometer's sketchpad on senior secondary school students' interest and achievement in geometry in Gboko Metropolis, Benue State. International Journal of Research \& Review. 5(4), 33-39.

Iwendi, B. C. (2012). Effects of gender and age on the mathematics achievement of secondary school students in Minna metropolis, Nigeria.Journal of Science, Technology, Mathematics and Education (JOSTMED) 9(1), 161-166.

Jega, S.H., Muhammad, S. Libata, I.A \& Kamba, A.H. (2018). The effect of two modes of computer assisted instruction on students' achievement and retention in mathematics in kebbi state. International Journal of Advanced Academic Research | Arts, Humanities \& Education 4(2),29-52.

Matawal, D. B.(2013). Analysis of the relationship between students' achievements in Mathematics In SSCE and remedial sciences programme, University of Jos Nigeria. Comprehensive Journal of Educational Research,1(3),42-46.

Mbugua Z.K. (2012). Factors contributing to students' performance in Mathematics at Kenya certificate of secondary education. A case of Baringo County, Kenya. American Journal of Contemporary Research. 2(6):87-91.

Miheso, K .M. (2012).Factors affecting mathematics performance among secondary school students in Nairobi province Kenya. Unpublished $\mathrm{PhD}$ thesis Kenyatta University. http://iriblary.ku.ac.ke/etd.handle/123456789/2485

Mishra, K. (2014). Effect of low tech tools for inclusive education in mathematics on attention regulation, academic achievement and numerical ability among the dyscalculic students of primary classes. A revised synopsis Submitted to Dayalbagh Educational Institute (Deemed University). 
Mutai, C.C. (2017).Gender differences in mathematics performance among secondary school students in Bureti Sub-County, Kericho County Kenya. Unpublished Master's Thesis. Kenyatta University.

Mwangi,S.W., Changeiywo, J.M.,\& Githua, B.N.(2020). Effects of computer animated teaching technique on secondary school students' geometry mathematics achievement by gender in Kitui County, Kenya. Researchjournali's Journal of Education 8(1),114.

Njoku, Z.C.\& Eze-Odurukwe, P.I. (2015). Resolving Nigerian secondary school students' learning difficulties in nuclear chemistry using animation solutions. Procedia- Social and Behavioral Sciences, 176, 1034-1040.

Odhiambo E.O.S, Maito.T. L. \& Ooko J. K. (2013). Teachers and students attitude towards mathematics in secondary schools in Siaya County, Kenya. Asian Journal of Management Sciences And Education 2 ( 3), 116-123.

Ogochukwu, N.V. (2015). Enhancing students interest in mathematics via multimedia presentation. African Journal of Mathematics and Computer Science Research 3(7),107-113.

Olunloye, O. (2010). Mass failure in mathematics: a national disaster. Tribune of 07/02/2010.retrieved from http/www.tribune.com.ng on 08/05/2011.

Osemwinyen, A. C. (2009). Effects of e- learning on retention and achievement in secondary school mathematics in Abuja, Nigeria. Unpublished Ph.D thesis, University of Nigeria, Nsukka.

Pierce, B. (2007). Linear associative algebra. American Journal of Mathematics. (4),1-4.

Sousa, D.A. (2011). "How the brain learns" (2nd Ed.). Thousand Oaks, CA: Corwin Press,

Tolu, O. T. (2009). Effects of computer animation and instruction model on the performance of students in senior secondary students biology in Minna Niger State, Nigeria. Unpublished Bachelor of Technology, (B, Tech) Project, Department of Science Education, Federal University of Technology, Minna, Nigeria.

Ugboduma, S.O.,Ezeamaenyi, M.O.N\& Ogbu,S. (2012). Effect of simulation- game cards on the teaching and learning of simple interest, profit and loss in Enugu state junior secondary schools. Global Journal of Educational Research 11(2), 115122.http://dx.doi.org/10.4314/gjedr.v11i2.6

Uwadiae, I. (2010). WAEC releases May/June WASSCE results. Thisday Newspaper of 20/8/2017.

Vale, C. (2009). Trends and factors concerning gender and mathematics in Australasia. From http://www.tsg.icmell.org/document/get/169 retrieved on 15, November 2013

Watkins,A.(2019). Knowledge Retention: 7 Proven Strategies for Healthcare Educators. 
https://www.ausmed.com/cpd/articles/knowledge-retention Retrieved on 10/8/2020.

Yara, P.O.\& Otieno, K.O. (2010). Teaching/ learning resources and academic performance in mathematics in secondary schools in Bondo District of Kenya. Asian Social Science 6(12),126-132. 10.5539/ass.v6n12p126

Yisa, N.C. \& Ojiaku, F.C. (2016). Effectiveness of computer animation on a progressive learning achievement of secondary school biology students in Niger State, Nigeria. International Journal of Education and Evaluation 2(4), 72-81. 